I N F ORM A T I R

Jurnal Informatika, Manajemen dan Komputer, Vol. 9, No. 2, Desember 2017

eISSN : 2580-3042

pISSN : 1979-0694

\title{
SISTEM PENGOLAHAN DATA PRODUKSI DAN PENJUALAN ES BALOK PADA UPT PPI KOTA DUMAI
}

\author{
Uci Yulia Sari ${ }^{1}$, Rahmad Kurniawan ${ }^{2}$, Adi Arianto ${ }^{3}$, Sukri Adrianto ${ }^{4}$ \\ ${ }^{1,2,3}$ Sekolah Tinggi Manajemen Informatika dan Komputer (STMIK) Dumai \\ Jl. Utama Karya Kel. Bukit Batrem Kec. Dumai Timur, Dumai-Riau 28811 \\ e-mail : uciyuliasari123@gmail.com
}

\begin{abstract}
ABSTRAK
Pengolahan data yang berbasis komputer telah berkembang sehingga banyak organisasi, sekolah, dan instansi memanfaatkan teknologi informasi dalam menunjang efektifitas dan efisiensi kerja. Unit pelaksana teknis pangkalan pendaratan ikan (UPT PPI) Salah satu instansi pemerintahan yang memproduksi dan menjual es balok di Kota Dumai. Dimana sistem yang ada saat ini pada proses pengolahan data produksi dan transaksi penjualan es balok masih kurang efisien karena menggunakan Microsoft Excel yang dapat memperlambat pekerjaan pegawai, Dan pada pembuatan laporan seperti laporan transaksi penjualan perhari, perbulan, atau pertahun juga membutuhkan waktu yang cukup lama karena harus menghitung satu per satu data yang ada dan sering terjadi keterlambatan dalam pemberian laporan kepada pimpinan. Oleh karena itu, diperlukan adanya sebuah sistem pengolahan data produksi dan transaksi penjualan es balok menggunakan Pemrograman PHP agar mempermudah pegawai dalam mengolah data serta dapat meminimalisirkan duplikasi data yang terjadi dan waktu yang digunakan dalam pencarian data lebih efisien.
\end{abstract}

Kata Kunci : Produksi, Penjualan, Es Balok, PHP.

\section{PENDAHULUAN}

Es balok merupakan air yang didinginkan kemudian dicetak menjadi balok es. Es balok mempunyai ukuran ada yang besar dan kecil tergantung masing-masing pabrik yang membuatnya. Dari pabriknya, es balok dijual per balok atau dalam keadaan utuh tidak bisa di pecah-pecah lagi menjadi bagian yang lebih kecil. Berbeda jika dari depot-depot atau penjual es balok, umumnya es balok dijual dalam ukuran yang lebih kecil. Hal itu, tergantung kebutuhan dari masing-masing konsumen.

Salah satu instansi pemerintahan yang memproduksi dan menjual es balok di Kota Dumai yaitu Unit Pelaksana Teknis Pangkalan Pendaratan Ikan (UPT PPI). PPI adalah pelabuhan khusus yang merupakan pusat pengembangan ekonomi perikanan, baik dilihat dari aspek produksinya maupun aspek pemasarannya. Dengan demikian maka PPI merupakan prasarana ekonomi yang berfungsi sebagai penunjang bagi perkembangan usaha perikanan laut maupun pelayanan. PPI merupakan tempat para nelayan mendaratkan ikan hasil tangkapannya dan menurut statusnya menjadi UPT PPI Kota Dumai. Fungsi UPT PPI Kota Dumai yaitu menyelenggarakan pengelolaan dan pelayanan sarana lelang, menyelenggarakan pengelolaan pabrik es dan penjualan es, menyelenggarakan pengelolan dan pelayanan jasa perbaikan alat tangkap ikan . UPT PPI Kota Dumai beralamat Jalan Pangkalan Pendaratan Ikan Kelurahan Pangkalan Sesai Kecamatan Dumai Barat.

UPT PPI Kota Dumai saat ini masih menggunakan sistem manual menggunakan microsoft excel untuk mengolah data produksi dan transaksi penjualan es balok, akan tetapi masih juga terdapat kesalahan seperti duplikasi data. Pada pencatatan produksi dan transaksi penjualan masih menggunakan sistem manual yang dapat memperlambat pekerjaan pegawai. Dan pada pembuatan laporan seperti laporan transaksi penjualan perhari, perbulan, atau pertahun juga membutuhkan waktu yang cukup lama karena harus menghitung satu per satu data yang ada dan sering terjadi keterlambatan dalam pemberian laporan kepada pimpinan.

Dalam penyelesaian masalah yang teridentifikasi dibutuhkan adanya suatu sistem yang mampu mengatasi masalah yang muncul serta untuk mengoptimalkan kinerja pengolahan data produksi dan transaksi penjualan es balok pada UPT PPI Kota Dumai menggunakan PHP . Dengan menggunakan Bahasa Pemrograman PHP dapat mempermudah mengolah data, dan 


\section{INFORM T I K}

Jurnal Informatika, Manajemen dan Komputer, Vol. 9, No. 2, Desember 2017

eISSN : 2580-3042

pISSN : 1979-0694

agar tidak terjadinya duplikasi data produksi dan transaksi penjualan serta keterlambatan dalam pembuatan laporan data produksi dan transaksi penjualan es balok.

Tujuan dilakukan penelitian ini adalah Merancang sistem pengolahan data produksi dan transaksi penjualan es balok berbasis PHP pada UPT PPI Kota Dumai, Mengurangi duplikasi data yang terjadi pada pencatatan produksi dan transaksi penjualan es balok pada UPT PPI Kota Dumai, Menyediakan sistem pengolahan data yang dapat mempermudah pegawai dalam sistem informasi data penjualan es balok dan memperoleh informasi yang berkaitan dengan semua transaksi maupun laporan.

\section{a. Sistem}

Sistem adalah sekelompok elemen yang saling berhubungan atau berinteraksi hingga membentuk satu persatuan. Konsep umum sistem adalah sekelompok komponen yang saling berhubungan, bekerja sama untuk mencapai tujuan bersama dengan menerima input serta menghasilkan output dalam proses transformasi yang teratur. Selain itu juga, sistem adalah elemen-elemen yang terinteraksi dengan maksud untuk mencapai tujuan organisasi atau perusahaan yang terdiri atas sejumlah sumber daya. Sumber daya tersebut bekerja menuju tercapainya suatu tujuan tertentu yang ditentukan oleh pemilik atau manajemen perusahaan tersebut. Jadi, dapat diambil kesimpulan bahwa sistem adalah sekelompok komponen yang saling behubungan dan bekerja sama untuk mencapai suatu tujuan bersama. (Indrajani, 2015)

\section{b. Informasi}

Informasi adalah Data yang telah diklasifikasikan atau diolah atau diinterprestasikan untuk digunakan dalam proses pengambilan keputusan. Sistem pengolahan informasi akan mengolah data menjadi informasi atau mengolah data dari bentuk tak berguna menjadi berguna bagi yang menerimanya. Nilai informasi berhubungan dengan keputusan. Bila tidak ada pilihan atau keputusan maka informasi tidak diperlukan. Keputusan dapat berkisar dari keputusan berulang sederhana sampai keputusan strategis jangka panjang. Nilai Informasi paling berarti dalam konteks pengambilan keputusan. (Sutabri, 2012)

\section{c. Pengolahan Data}

Pengolahan data adalah suatu proses menerima data sebagai masukan (input) memproses (processing) menggunakan proses tertentu, dan mengeluarkan hasil proses data

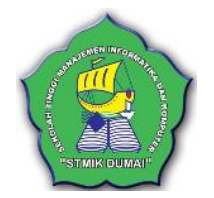

tersebut dalam bentuk informasi (output). (Mahyuni, Sharipuddin, \& Martono, 2014)

\section{d. Produksi}

Produksi adalah semua kegiatan dalam menciptakan atau menambah kegunaan barang atau jasa, dimana untuk kegiatan tersebut diperlukan faktor-faktor produksi. (Honainah, 2016)

\section{e. Penjualan}

Penjualan adalah suatu sistem keseluruhan dari kegiatan usaha yang ditujukan untuk merencanakan, menentukan harga, mempromosikan dan mendistribusikan barang, jasa, ide kepada pasar pasaran agar dapat mencapai tujuan organisasi. (Rejeki, Utomo, \& Susanti, 2011)

\section{f. PHP ( Hypertext Preprocessor)}

PHP adalah singkatan dari "PHP : Hypertext Preprocessor", yang merupakan sebuah bahasa scripting yang terpasang pada HTML untuk membuat webside yang dinamis. PHP ini merupakan server side scripting maksunya sintak dan perintah perintah PHP akan dieksekusi deserver kemudian hasilnya baru ditampilkan ke browser dalam format HTML, maka kode kode yang anda tulis menggunakan PHP tidak akan kelihatan oleh user sehingga membuat halaman website anda lebih aman dan dinamis. PHP ini bersifat open source sehingga source code nya dapat diubah ubah dan dapat didistribusikan dengan bebas. PHP ini juga mampu lintas platform maksudnya PHP bisa dijalankan dibanyak system operasi seperti disemua versi Microsoft windows, Linux. (Dahlan, 2013)

\section{g. Pengertian MySQL}

MySQL adalah RDBMS yang cepat dan mudah digunakan, serta sudah banyak digunakan untuk berbagai kebutuhan. MySQL dikembangkan oleh MySQL AB Swedia . Berikut ini hal-hal yang menyebabkan MySQL menjadi begitu populer:

1. Berlisensi Open-source, sehingga anda dapat menggunakannya secara gratis.

2. Merupakan program yang powerful dan menyediakan fitur yang lengkap.

3. Menggunakan bentuk standar bahasa data $S Q L$

4. Dapat bekerja dengan banyak sistem operasi dan dengan bahasa-bahasa pemrograman seperti PHP, PERL, C, C++,JAVA, dan lain-lain.

5. Bekerja dengan cepat dan baik, bahkan dengan data set yang banyak. 
IN F ORM T I K

Jurnal Informatika, Manajemen dan Komputer, Vol. 9, No. 2, Desember 2017

eISSN : 2580-3042

pISSN : 1979-0694

6. Sangat mudah digunakan dengan PHP untuk pengembangan aplikasi web.

7. Mendukung banyak database, sampai 50 juta baris atau lebih dalam suatu tabel.

8. Dapat dikostumisasi sesuai dengan keinginan anda. (Enterprise, 2014)

\section{METODE PENELITIAN}

Adapun metode yang digunakan dalam penelitian ini berisikan kerangka kerja / tahapantahapan kerja yang dilakukan guna menyelesaikan permasalahan, yaitu sebagai berikut:

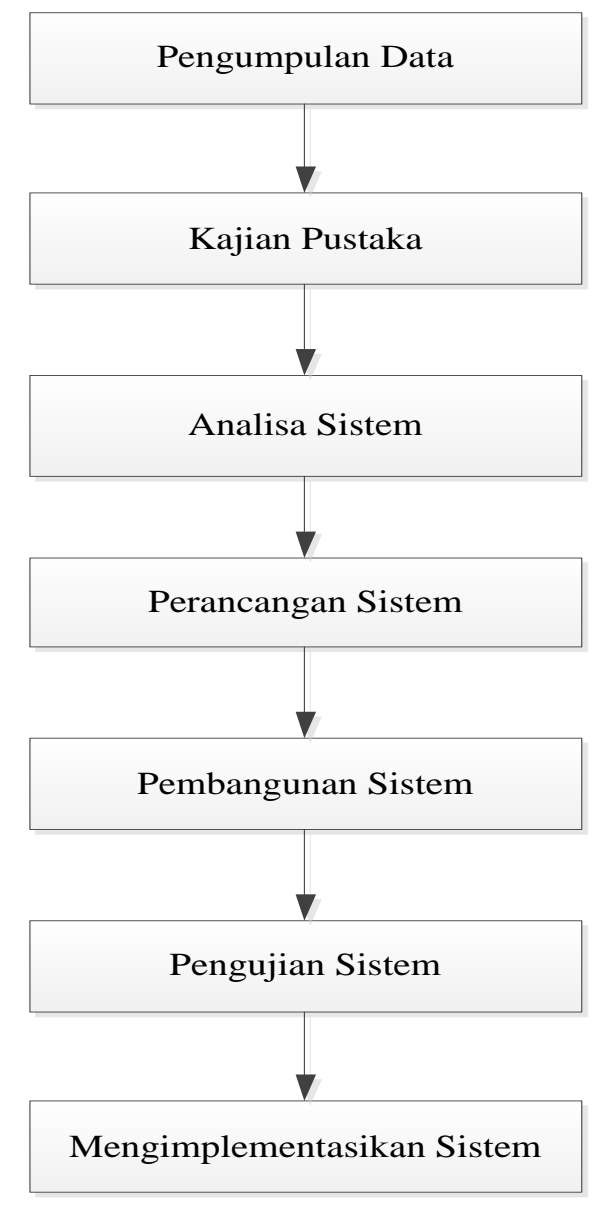

Gambar 1. Kerangka Kerja Penelitian

Adapun penjelasan dari kerangka kerja penelitian diatas adalah :

1. Pengumpulan Data

Pengumpulan data mengenai data es balok diperoleh dengan cara melakukan proses tanya jawab langsung kepada salah satu pegawai yang ada pada UPT PPI Kota dumai, proses tanya jawab dilakukan untuk mendapatkan informasi yang akurat.

\section{Kajian Pustaka}

Pada tahap ini dilakukan untuk pencarian data dengan membaca dan mempelajari berbagai buku-buku, internet serta pengetahuan yang berhubungan dengan masalah yang akan diteliti yaitu pengolahan data produksi dan penjualan es balok.

\section{Analisa Sistem}

Pada tahap ini dilakukan pengamatan, mempelajari, dan memahami data produksi dan penjualan es balok . melalui analisa dokumen input dan output sehingga diketahui kelebihan dan kelemahan sistem yang sedang berjalan. pada sistem yang sedang berjalan penyimpanan data produksi dan penjualan es balok yang digunakan masih menggunakan sistem manual sehingga terdapat kesalahan penyajian laporan kepada pimpinan tidak dapat disediakan dengan cepat .

\section{Perancangan Sistem}

Beberapa perancangan sistem yang akan di buat pada tahap ini yaitu : Aliran Sistem Informasi (ASI), Context Diagram, Data Flow Diagram (DFD), Entity Relationship Diagram (ERD), Bagan Alir (Flowchart), Perancangan Input dan Output, Perancangan Database

\section{Pembangunan Sistem}

Pada tahap ini dilakukan pembangunan sistem berdasarkan perancangan sistem yang telah dilakukan sebelumnya. Pembangunan sistem ini berupa pembuatan perangkat lunak menggunakan Bahasa Pemrograman PHP.

\section{Pengujian Sistem}

Pada tahap ini dilakukan pengujian program dengan menjalankan program dan memperbaiki apabila terdapat kesalahan, serta memastikan bahwa program yang telah dirancang layak untuk diimplementasikan.

\section{Mengimplementasikan Sistem}

Setelah rancangan selesai dibuat, maka pada tahap ini dilakukan pengimplementasian sistem untuk menerapkan program yang telah dibuat. 
I N F ORM A T I R

Jurnal Informatika, Manajemen dan Komputer, Vol. 9, No. 2, Desember 2017

eISSN : 2580-3042

pISSN : 1979-0694

\section{HASIL DAN PEMBAHASAN}

a. Analisis Sistem

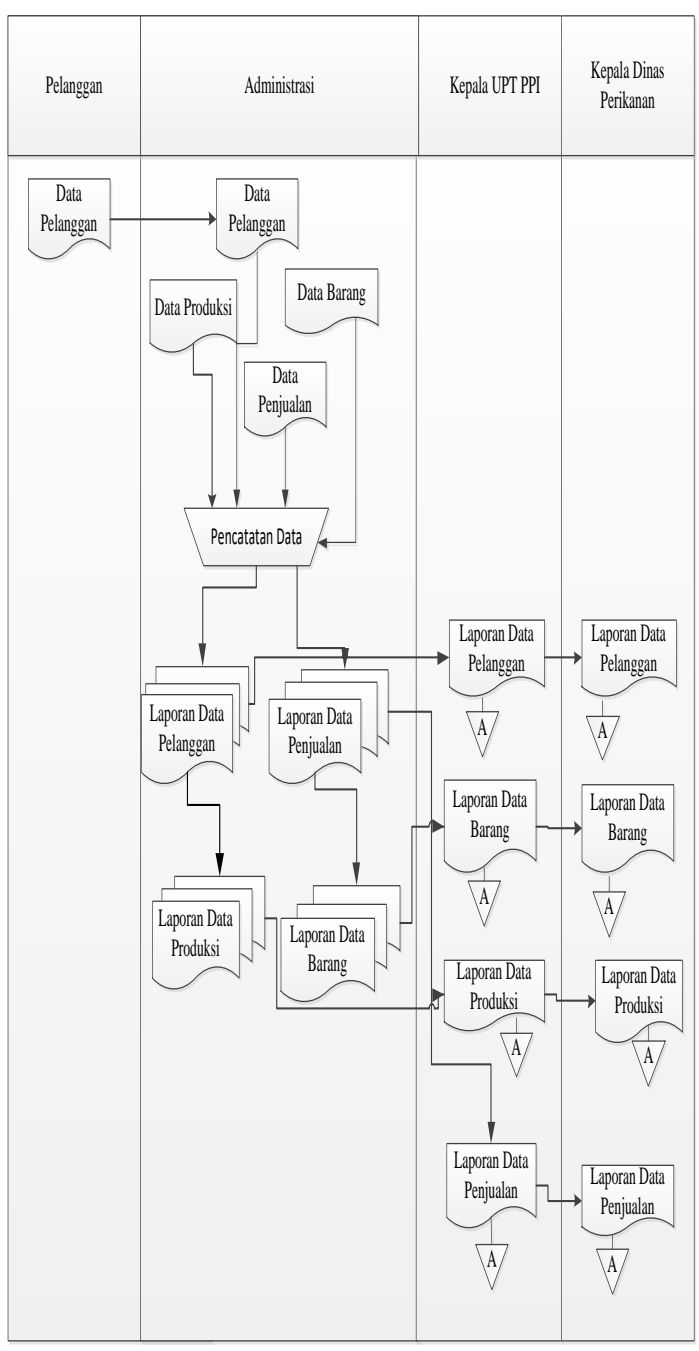

Gambar 2. ASI Yang Sedang Berjalan

Berdasarkan gambar 2 ini dapat disimpulkan bahwa:

1. Pelanggan memberikan datanya kepada bagian adminitrasi,

2. Adminitrasi melakukan pencatatan secara manual, yaitu data pelanggan, data barang, data produksi, data penjualan.

3. Ketika sudah melakukan pencatatan, maka menghasilkan beberapa laporan yaitu : laporan data produksi, laporan data penjualan, laporan data barang dan laporan data pelanggan,

4. Lalu masing-masing laporan tersebut diberikan kepada Kepala UPT PPI dan Kepala Dinas Perikanan

5. Dan diarsipkan

\section{b. Analisis Kebutuhan Sistem}

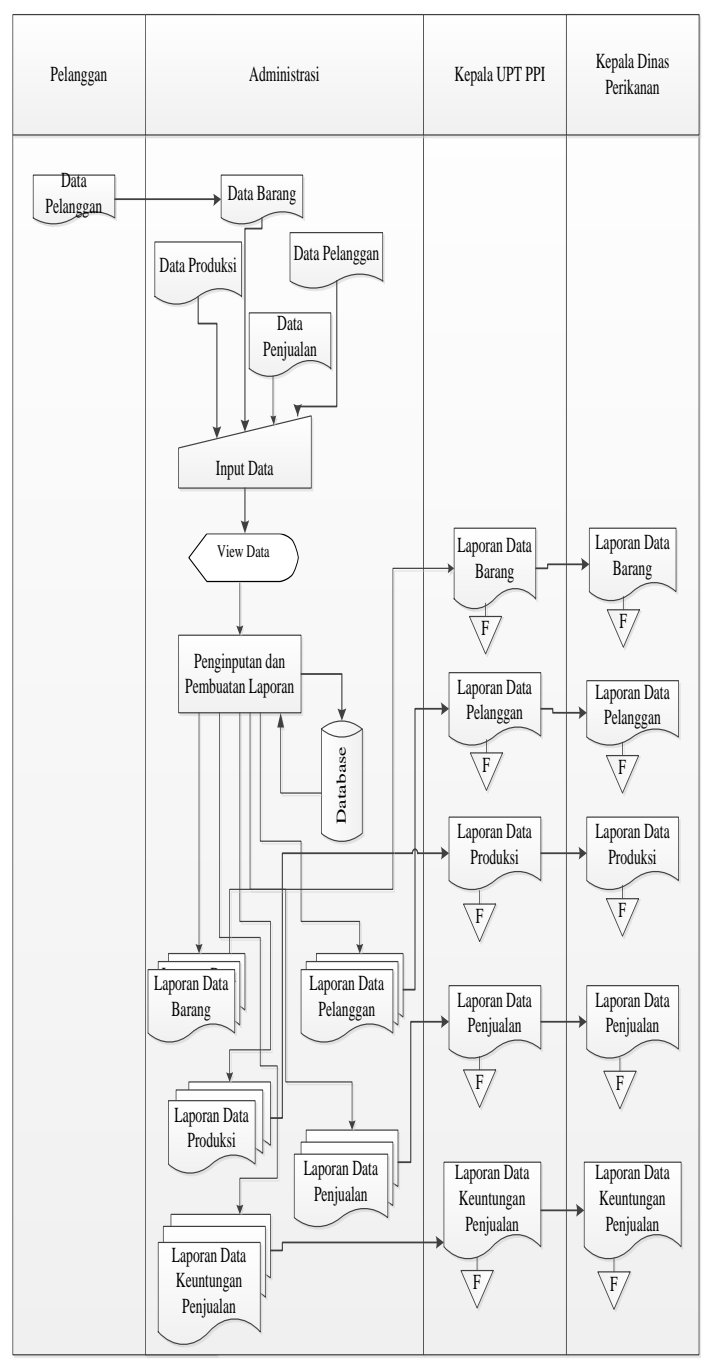

Gambar 3. ASI Baru

Berdasarkan gambar 3 ini dapat disimpulkan bahwa:

1. Data barang, data pelanggan, data produksi, dan data penjualan di inputkan oleh adminitrasi secara komputerisasi,

2. Ketika sudah melakukan penginputan dan menghasilkan beberapa laporan yaitu: laporan data barang, laporan data pelanggan, laporan data produksi, laporan data penjualan, dan laporan data keuntungan penjualan.

3. Lalu laporan tersebut diberikan kepada kepala UPT PPI dan kepala Dinas Perikanan Kota Dumai dan diarsipkan.

4. Penginputan tadi tersimpan kedalam database dan bisa dilihat melalui monitor komputer dll. 
I N F O R M A T I K

Jurnal Informatika, Manajemen dan Komputer, Vol. 9, No. 2, Desember 2017

eISSN : 2580-3042

pISSN : 1979-0694

\section{c. Permodelan Proses}

1. Context Diagram

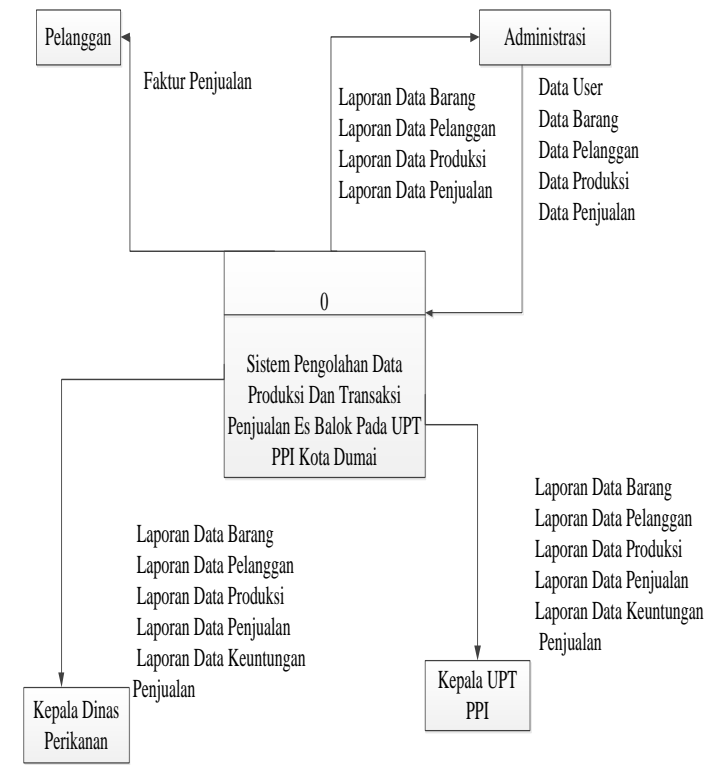

Gambar 4. Context Diagram

2. Data Flow Diagram

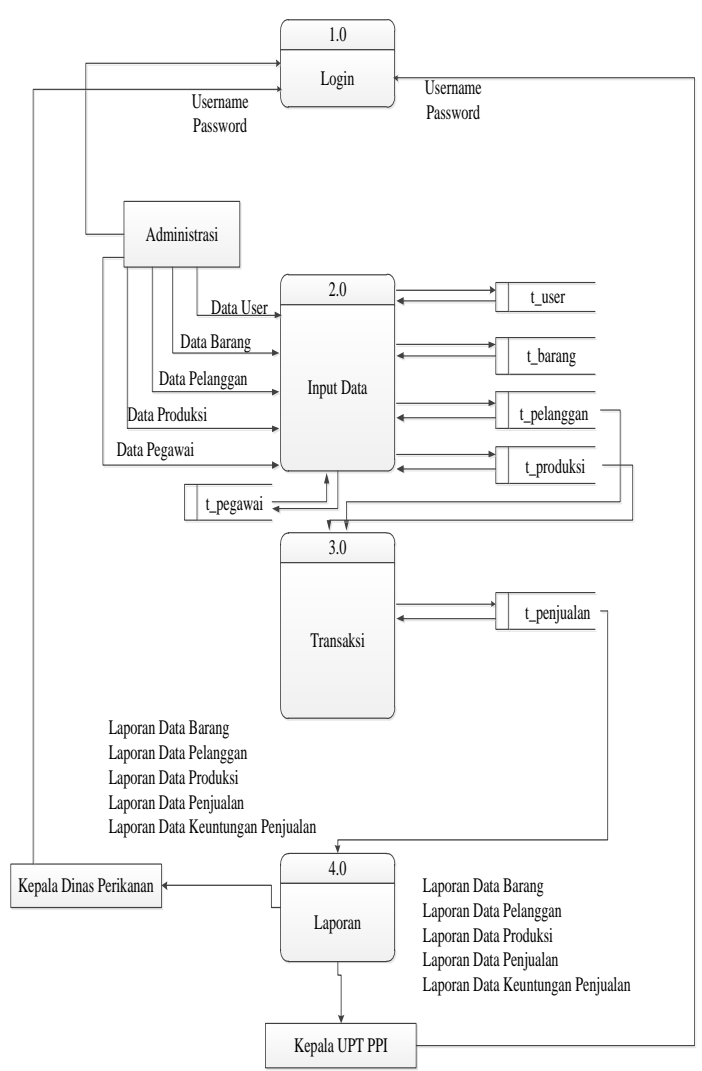

Gambar 5. Data Flow Diagram d. Permodelan Data

Entity Relationship Diagram (ERD)

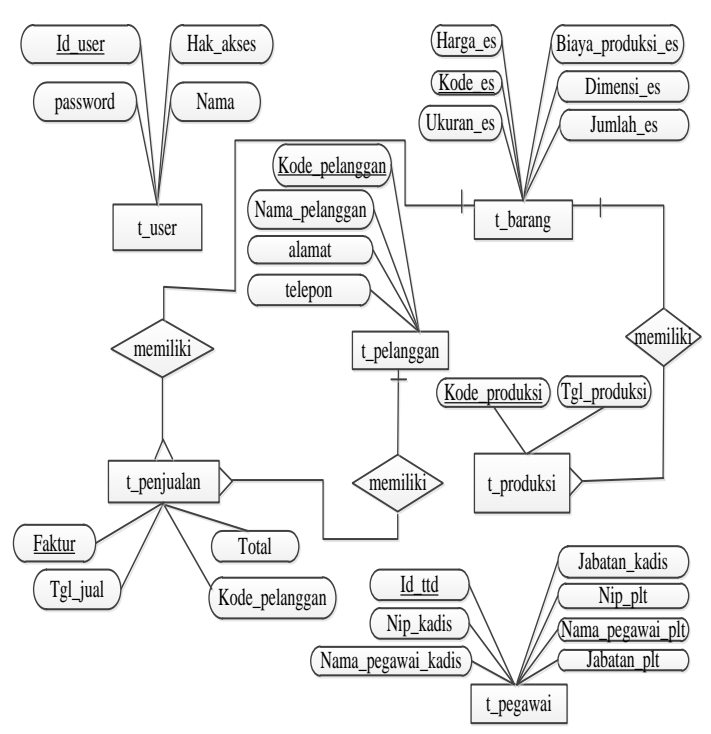

Gambar 6. Entity Relationship

Diagram(ERD)

\section{e. Struktur Program (HIPO)}

Adapun Struktur Program (HIPO) dapat dilihat pada gambar 8 sebagai berikut :

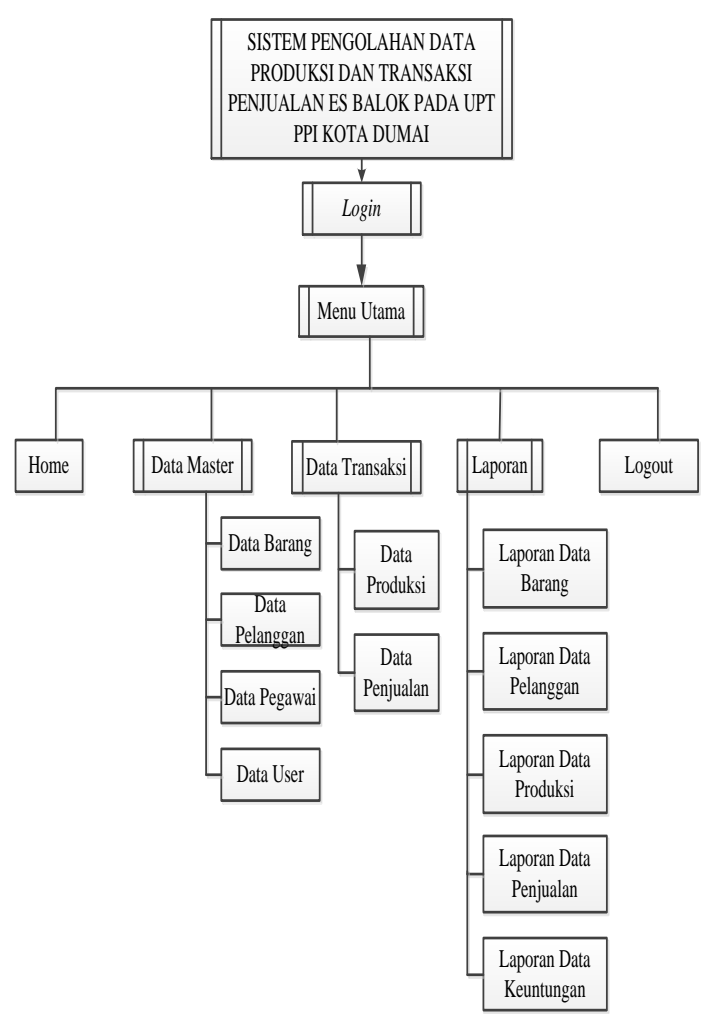

Gambar 7. Struktur Program (HIPO) 
I N F O R M A T I K A

Jurnal Informatika, Manajemen dan Komputer, Vol. 9, No. 2, Desember 2017

eISSN : 2580-3042

pISSN : 1979-0694

\section{f. Implementasi Sistem}

1. Tampilan Login

Untuk menjalankan program pertama kali, dibutuhkan akses lokal server untuk menjalankan program. Gunakan lokal server seperti Хampp , Wampp dan lainnya .

1. Aktifkan Apache dan $M y S q l$

2. Buka browser (Mozila firefox, google chrome, dll )

3. Ketikkan url (alamat) program aplikasi yaitu : localhost/webku/Program Skripsi/

4. lalu jalankan.

(i) http://localhost/webku/Program Skripsi/

Gambar 8. Alamat url program

5. Muncul tampilan login untuk mengakses program aplikasi

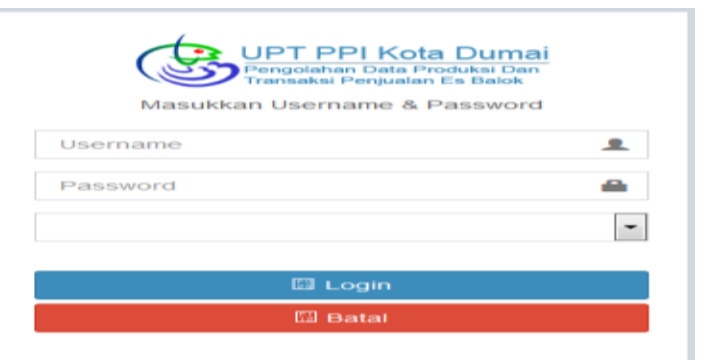

Gambar 9. Tampilan Login

6. Masukkan Id User, dan Password yang telah terdaftar. jika Id User dan Password di isi dengan benar maka program aplikasi utama akan terbuka.

\section{Tampilan Menu Utama}

Dalam tampilan menu utama atau halaman utama ini terdapat beberapa menu yang memiliki fungsi dan kegunaan masing-masing.

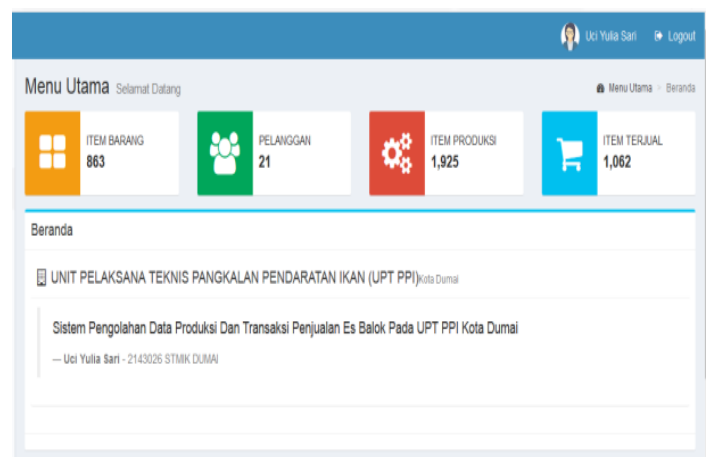

Gambar 10. Tampilan Menu Utama
1. Menu Home berfungsi menampilkan halaman utama aplikasi

2. Menu Master berfungsi untuk menampilkan data-data master dimana dalam menu master ini terdapat 4 (empat) form, yaitu : form data barang, form data pelanggan, form data pegawai, form data user.

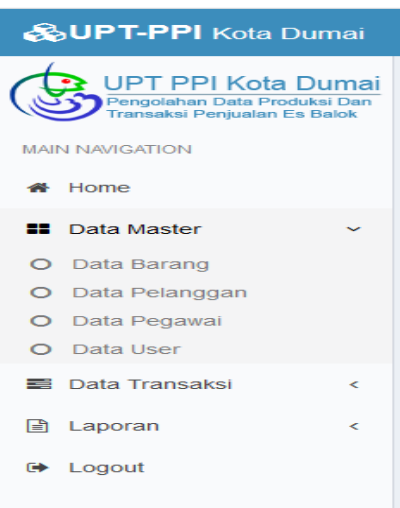

Gambar 11. Form Menu Master

3. Menu Transaksi berfungsi untuk menampilkan data transaksi dimana dalam menu transaksi ini terdapat 2 (dua) form yaitu : form data produksi dan data penjualan.

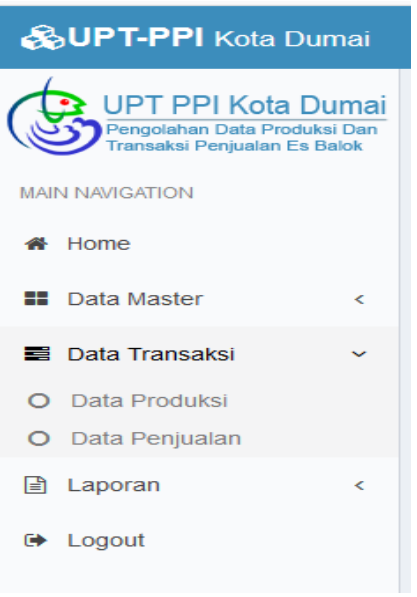

Gambar 12. Form Menu Transaksi

4. Menu Laporan berfungsi untuk menampilkan data-data laporan dimana dalam menu laporan ini terdapat 5 (Lima) form, yaitu : form laporan data barang, form laporan data pelanggan , form laporan data produksi , form laporan data penjualan, form laporan data keuntungan . 
IN F O R M A T I A

Jurnal Informatika, Manajemen dan Komputer, Vol. 9, No. 2, Desember 2017

eISSN : 2580-3042

pISSN : 1979-0694
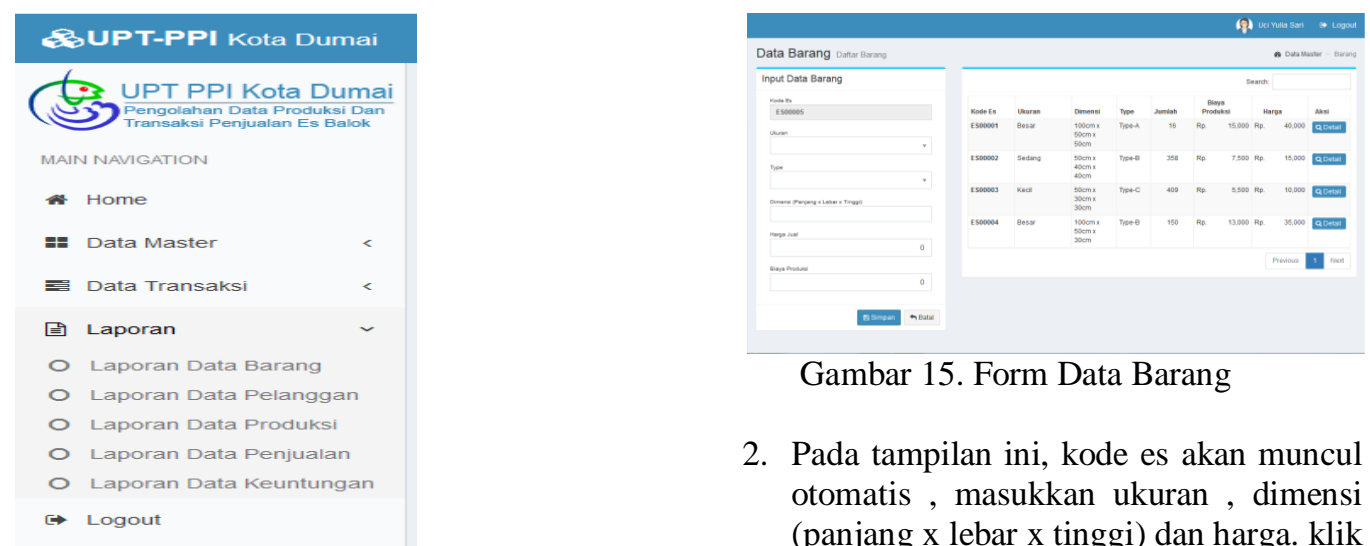

Gambar 15. Form Data Barang

2. Pada tampilan ini, kode es akan muncul otomatis , masukkan ukuran, dimensi (panjang $\mathrm{x}$ lebar $\mathrm{x}$ tinggi) dan harga. klik simpan untuk menyimpan, klik batal untuk membatalkan data yang sudah dimasukkan.

3. Tampilan Menu Master

a. Data User

1. Ketika menu master data user di klik , maka tampilan view data user akan muncul, Pada tampilan view data user berisikan data - data yang sudah di input dan disimpan pada database . dan jika ingin mengubah atau menghapus data yang sudah ada tersebut, klik ikon yang ada pada kolom detail .

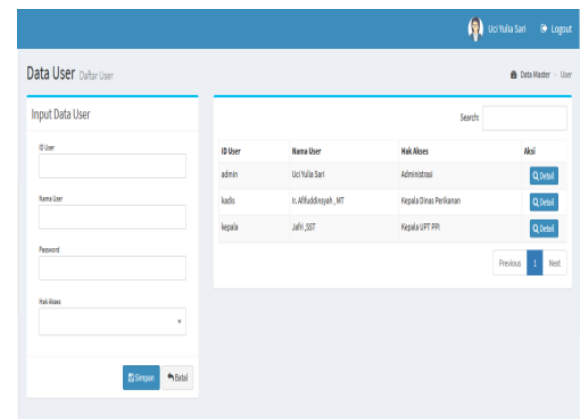

Gambar 14. Form Data User

2. Pada tampilan ini, masukkan id user , password dan pilih hak akses sesuai dengan jabatan yang dijabati. klik simpan untuk menyimpan, klik batal untuk membatalkan data yang sudah dimasukkan .

b. Data Barang

1. Ketika menu master data barang di klik, maka tampilan view data barang akan muncul, Pada tampilan view data barang berisikan data - data yang sudah diinput dan disimpan pada database . dan jika ingin mengubah atau menghapus data yang sudah ada tersebut, klik ikon yang ada pada kolom detail .

c. Data Pelanggan

1. Ketika menu master data pelanggan di klik, maka tampilan view data pelanggan akan muncul, Pada tampilan view data pelanggan berisikan data - data yang sudah diinput dan disimpan pada database . dan jika ingin mengubah atau menghapus data yang sudah ada tersebut, klik ikon yang ada pada kolom detail .

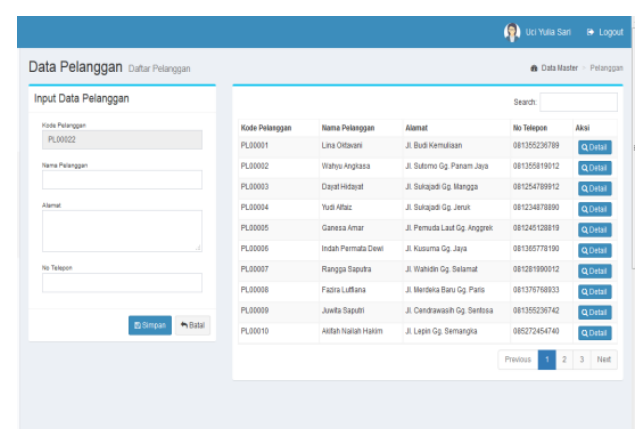

Gambar 16. Form Data Pelanggan

2. Pada tampilan ini, kode pelanggan akan muncul otomatis, masukkan nama pelanggan , alamat dan no telepon. klik simpan untuk menyimpan, klik batal untuk membatalkan data yang sudah dimasukkan.

\section{d. Data Pegawai}

Ketika menu master data pegawai di klik, maka form data pegawai akan muncul dan pada tampilan ini, masukkan nip , nama pegawai dan jabatan. klik simpan untuk menyimpan, klik batal untuk membatalkan data yang sudah dimasukkan. 
INFORM T IKA

Jurnal Informatika, Manajemen dan Komputer, Vol. 9, No. 2, Desember 2017

eISSN : 2580-3042

pISSN : 1979-0694

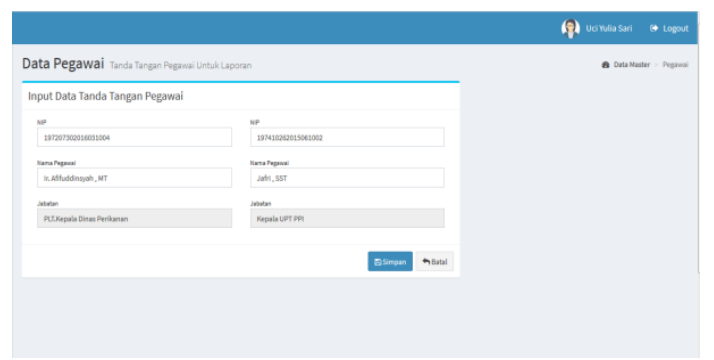

Gambar 17. Form Data Pegawai

4. Tampilan Menu Transaksi

a. Data Produksi

1. Ketika menu transaksi data produksi di klik, maka tampilan view data produksi akan muncul, Pada tampilan view data produksi berisikan data - data yang sudah diinput dan disimpan pada database . dan jika ingin mengubah atau menghapus data yang sudah ada tersebut, klik ikon yang ada pada kolom detail .

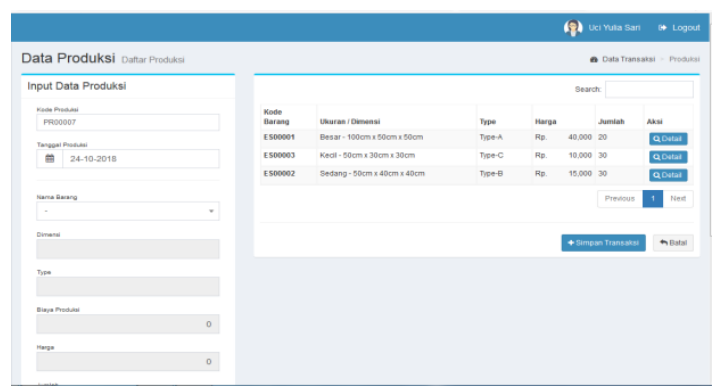

Gambar 18. Form Data Produksi

2. Pada tampilan ini, kode produksi akan muncul otomatis , masukkan tanggal produksi , nama barang, dimensi, harga dan jumlah. klik tambah item untuk menambah data produksi, klik simpan transaksi untuk menyimpan, dan klik batal untuk membatalkan data yang sudah dimasukkan .

b. Data Penjualan

1. Ketika menu transaksi data penjualan di klik , maka tampilan view data penjualan akan muncul, Pada tampilan view data penjualan berisikan data data yang sudah di input dan disimpan pada database . dan jika ingin mengubah atau menghapus data yang sudah ada tersebut, klik ikon yang ada pada kolom detail.

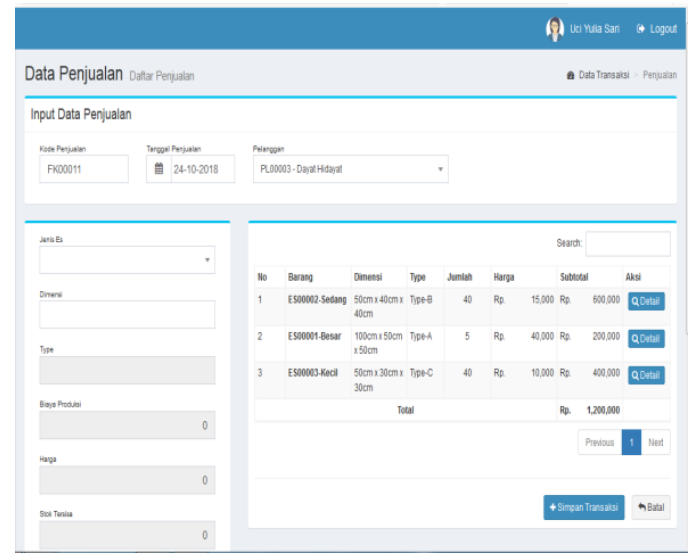

Gambar 19. Form Data Penjualan

2. Pada tampilan ini, kode penjualan akan muncul otomatis, masukkan tanggal penjualan, pelanggan, jenis es, dimensi , harga , stok tersisa dan jumlah penjualan. klik tambah item untuk menambah data penjualan, klik simpan transaksi untuk menyimpan, dan klik batal untuk membatalkan data yang sudah dimasukkan .

5. Tampilan Menu Laporan

a. Laporan Data Produksi

Ketika laporan data produksi di klik, maka akan muncul tampilan view laporan data produksi. Laporan produksi terdapat 3 laporan yaitu : laporan harian, laporan bulanan, dan laporan tahunan.

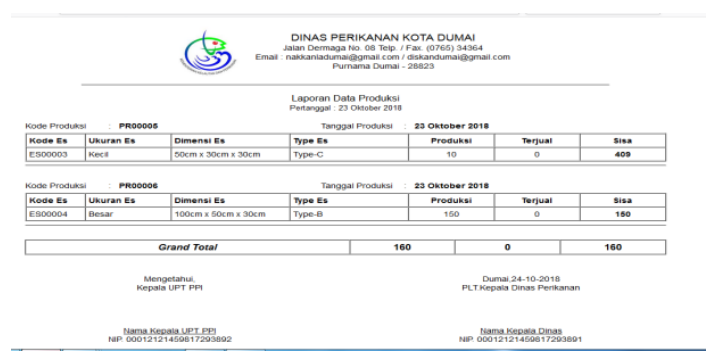

Gambar 20. Laporan Data Produksi

b. Laporan Data Penjualan

Ketika laporan data penjualan di klik, maka akan muncul tampilan view laporan data penjualan. Laporan penjualan terdapat 3 laporan yaitu : laporan harian, laporan bulanan, dan laporan tahunan. 
INFORM A I I A

Jurnal Informatika, Manajemen dan Komputer, Vol. 9, No. 2, Desember 2017

eISSN : 2580-3042

pISSN : 1979-0694

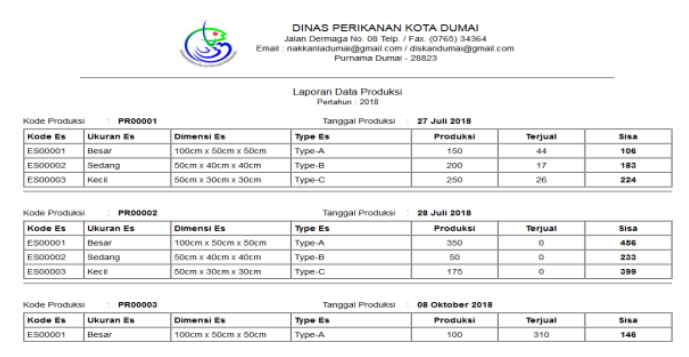

Gambar 21. Laporan Data Penjualan

\section{KESIMPULAN}

Berdasarkan hasil pembahasan yang telah diuraikan pada bab-bab sebelumnya, dapat diambil kesimpulan sebagai berikut :

1. Dengan dirancangnya sebuah aplikasi “ Sistem pengolahan data produksi dan transaksi penjualan es balok ". Menggunakan pemrograman serta mendukung untuk pembuatan laporan maka dapat dihasilkan suatu laporan dengan cepat karena data tersusun dan tersimpan dalam media penyimpanan komputer.

2. Dengan menerapkan sistem ini, maka pengolahan data produksi dan transaksi penjualan es balok pada UPT PPI Kota Dumai seperti penambahan, penghapusan, pencarian, dan pembuatan laporan akan dapat diatasi dalam waktu singkat serta dapat meminimalkan kesalahan yang terjadi.

3. Dengan adanya sistem ini, memungkinkan variasi bentuk laporan dapat diperbanyak , tidak hanya mampu mencetak hasil transaksi laporan harian melainkan juga bisa mencetak laporan bulanan dan tahunan.

\section{REFERENSI}

Dahlan, M. (2013). Membuat Web PHP. (Irma \& Eti, Eds.). Yogyakarta: CV. Mitra Utama.

Enterprise, J. (2014). MySQL Untuk Pemula. Jakarta: PT. Elex Media Komputindo.

Fadillah, Y., \& Suprianto. (2017). Sistem Informasi Penjualan Produk Krupuk Berbasis Web Responsive (Studi Kasus: UD. Sumber Makmur). Jurnal Sistem Informasi, Teknologi Informasi Dan Komputer, 8(1), 31-37.

Honainah. (2016). Rekapitulasi Data Produksi Ikan Pada Unit Pelaksana Teknis Tempat Pelelangan Ikan (UPT PPI) Berbasis Python dan MySQL, 2(1), 33-38.

Indrajani. (2015). Database Design. Jakarta: PT. Elex Media Komputindo.

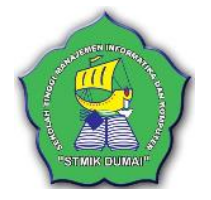

Mahyuni, Sharipuddin, \& Martono. (2014). Perancangan Sistem Pengolahan Data Pada SMA Negeri 6 Kabupaten Tebo. Jurnal Ilmiah Media SISFO, 8(3), 180-187.

Offset, A. (2014). Sistem Informasi Penjualan Online Untuk Tugas AKhir. (Ignas, Ed.). Yogyakarta.

Rejeki, R. S. A., Utomo, A. P., \& Susanti, S. S. (2011). Perancangan dan Pengaplikasian Sistem Penjualan pada "Distro Smith" Berbasis E--Commerce. Jurnal Teknologi Informasi Dinamik, 16(1), 150-159.

Saiful, \& Rahman, B. (2016). Sistem Informasi Hasil Produksi Dan Penjualan Roti Pada Usaha Dagang Lala Roti Kendari. Jurnal Sistem Informasi Dan Teknik Komputer Catur Sakti, 1(1), 53-61.

sentosa, Y., Hadiansa, A., \& Rubiati, N. (2017). Aplikasi Pembuatan Kartu Pengenal Siswa Dan Siswi Sekolah Menengah Pertama (Smp) Ykpp Dumai. Jurnal Informatika, Manajemen Dan Komputer, 9(1), 44-48. Retrieved from http://www.ejournal.stmikdumai.ac.id/inde x.php/path/article/view/63

Sutabri, T. (2012). Analisis Sistem Informasi. (C. Putri, Ed.). Yogyakarta: CV. Andi Offset.

Yunita, P. (2018). Aplikasi Perhitungan Payroll Dosen Pada STMIK Dumai. Jurnal Informatika, Manajemen Dan Komputer, 10(1), 18-21. Retrieved from http://www.ejournal.stmikdumai.ac.id/Inde x.Php/Path/Article/View/56 